\title{
ANALISIS PENGARUH KOMPOSISI DEWAN KOMISARIS TERHADAP KINERJA KEUANGAN PERUSAHAAN PERBANKAN DI INDONESIA
}

\author{
Herdyanto ${ }^{1)}$
}

1) dosen universitas pamulang, email : herdyk@gmail.com

\section{ARTICLES \\ INFORMATION}

JURNAL SEKURITAS

(Saham, Ekonomi, Keuangan dan Investasi )

Vol.2, No.2, Januari 2019

Halaman : $14-32$

C LPPM \& Prodi Manajemen

UNVERSITAS PAMULANG

ISSN (online) : 2581-2777

ISSN (print) : :2581-2696

Keyword :

GCG, Komposisi Dewan

Komisaris, ROA, ROE.

JEL. classification :

C33, G21, G34, N25

\section{Contact Author :}

PRODI MANAJEMEN UNPAM

JL.Surya Kencana No.1 Pamulang

Tangerang Selatan - Banten

Telp. (021) 7412566, Fax (021) 7412491 Email:

jurnalfinance.unpam@gmail.com
Komposisi Dewan Komisaris sebagai bagian dari mekanisme GCG (Good Corporate Governance) mendapat perhatian yang serius dari perusahaan dan pemerintah. Peran yang efektif dari Dewan Komisaris diharapkan mampu meningkatkan kinerja perusahaan. Tujuan penelitian ini untuk mengetahui pengaruh pengaruh Komposisi Dewan Komisaris pada kinerja keuangan perusahan perbankan yang terdaftar di Bursa Efek Indonesia selama tahun 2003 - 2007.variabel yang digunakan dalam penelitian ini adalah Board Size, Board Composition, Firm Size, Non-Performing Loan, dan Financial Leverage. Variable dependen yang digunakan adalah Kinerja Keuangan (ROA dan $\mathrm{ROE}$ ). Berdasarkan data yang digunakan dalam penelitian ini didapat hasil bahwa Dewan Komisaris tidak memiliki pengaruh yang signifikan terhadap Kinerja Perusahaan (ROA dan ROE).

Board composition as part of GCG's mechanism have a serious attention for companies and the governments. The effective role of the board is expected to be able to increase performance of the company. The objective of this research is to examine the influence of board composition on financial performances among listed banking companies at Indonesian Stock Exchange 20032007. Independent variables at this research are Board Size, Board Composition, Firm Size, Non-Performing Loan, and Financial Leverage. As dependent variable is Financial Performances (ROA and ROE). Data which used in this research is data of secondary obtained of Indonesia Stock Exchange and Indonesian Capital Market Directory. The data is reckoned from financial report ending in the year of 2003 - 2007. The result of this research concluded that Board composition didn't have significant influence to financial performance (ROA and ROE). 


\section{A. Pendahuluan}

Dewasa ini hadirnya Good Corporate Governace (GCG) bagi setiap perusahaan menjadi mutlak diperlukan karena GCG mensyaratkan suatu pengelolaan yang baik bagi suatu perusahaan. Perhatian terhadap GCG ini terutama juga dipicu oleh skandal spektakuler perusahaan-perusahaan publik di Amerika dan Eropa, seperti Enron, Worldcom, Tyco, London \& Commonwealth, Poly Peck, Maxwell, dan lain-lain. Cadbury Report (UK) dan Treadway Report (US) mengatakan bahwa keruntuhan perusahaanperusahaan public tersebut dikarenakan oleh kegagalan strategi maupun praktek curang dari manajemen puncak yang berlangsung tanpa terdeteksi dalam waktu yang cukup lama karena lemahnya pengawasan yang independen oleh corporate boards (Daniri, 2005).

Corporate Governance dalam arti sempit pada dasarnya berbicara tentang dua aspek yakni governance structure atau board structure dan governance process atau governance mechanism pada suatu perusahaan. Governance structure adalah struktur hubungan pertanggungjawaban dan pembagian peran antara berbagai organ utama perusahaan yakni pemilik/pemegang saham, pengawas/komisaris, dan pengelola/direksi/manajemen. Governance process membicarakan tentang mekanisme kerja dan interaksi aktual di antara organ-organ tersebut. Meskipun pada dasarnya governance process dipengaruhi oleh governance structure, mekanisme kerja dan interaksi aktual di antara organ-organ korporasi dapat berjalan menyimpang dari struktur yang ada (Alijoyo dan Zaini, 2004).

Terbentuknya sistem corporate governance ini dipengaruhi oleh teori mengenai konflik antara pemilik dan manajemen perusahaan. Dua teori utama yang mendasarinya adalah stewardship theory dan agency theory. Dalam perkembangan selanjutnya, agency theory mendapat respon lebih luas karena dipandang lebih mecerminkan kenyataan yang ada. Berbagai pemikiran mengenai corporate governance berkembang dengan bertumpu pada agency theory dimana pengelola perusahaan harus diawasi dan dikendalikan untuk memastikan bahwa pengelolaan dilakukan dengan penuh kepatuhan kepada berbagai peraturan dan ketentuan yang berlaku.

Dalam terbitannya mengenai GCG yang berjudul "Peranan Dewan Komisaris dan Komite Audit dalam Pelaksanaan Corporate Governance (Tata Kelola Perusahaan)", Forum for Corporate Governance in Indonesia (FCGI) mengatakan bahwa prinsip-prinsip Corporate Governance dari OECD menyangkut hal-hal sebagai berikut:

1. Hak-hak para pemegang saham;

2. Perlakuan yang sama terhadap para pemegang saham;

3. Peranan semua pihak yang berkepentingan (stakeholder) dalam Corporate Governance;

4. Transparansi dan penjelasan; dan

5. Peranan Dewan Komisaris

Menurut Egon Zehnder, Dewan Komisaris merupakan inti dari Corporate Governance yang ditugaskan untuk menjamin pelaksanaan strategi perusahaan, mengawasi manajemen dalam pengelolaan perusahaan, dan mewajibkan terlaksananya akuntabilitas. Pada intinya Dewan Komisaris merupakan suatu mekanisme mengawasi dan mekanisme untuk memberikan petunjuk dan arahan pada pengelola perusahaan. Mengingat manajemen yang bertanggung jawab untuk meningkatkan efisiensi dan daya 
saing perusahaan sedangkan Dewan Komisaris bertanggung jawab untuk mengawasi manajemen, maka Dewan Komisaris merupakan pusat ketahanan dan kesuksesan perusahaan (Egon Zehnder International, 2000 dalam FCGI).

Menurut Alijoyo dan Zaini (2004), Corporate Governance diartikan sebagai suatu hal yang berkaitan dengan pengambilan keputusan yang efektif yang bersumber dari budaya perusahaan, etika, sistem nilai, proses bisnis, kebijakan dan struktur organisasi, yang bertujuan mendorong:

1. Pertumbuhan Kinerja Perusahaan;

2. Pengelolaan sumber daya dan risiko secara efisien dan efektif; dan

3. Pertanggungjawaban perusahaan kepada pemegang saham dan stakeholder lainnya.

Dari penjelasan di atas diketahui bahwa GCG sangat terkait dengan Peranan Dewan Komisaris yang dengan peranannya yang efektif diharapkan akan mampu meningkatkan pertumbuhan kinerja perusahaan.

Dalam penelitian yang telah dilakukan oleh banyak peneliti, termasuk oleh Sanda et. al. (2005) disebutkan beberapa hal yang termasuk dalam mekanisme corporate governance, yaitu antara lain: kepemilikan saham oleh pihak internal, komposisi dewan komisaris, ukuran/jumlah dewan komisaris, konsentrasi kepemilikan, dan the role of debt.

Sejak diakuinya komposisi dewan komisaris dan ukuran / jumlah dewan komisaris sebagai bagian dari mekanisme GCG, maka pentingnya kedua hal tersebut mendapat perhatian yang sangat serius dari berbagai perusahaan, tak terkecuali oleh pemerintah Indonesia sendiri. Hal ini terbukti dengan diaturnya kedua hal tersebut dalam Peraturan Bank Indonesia nomor 8/4/PBI/2006 dan 8/14/PBI/2006 tahun 2006 dan Undang-undang Republik Indonesia nomor 40 tahun 2007 mengenai Perseroan Terbatas. Sedangkan untuk perusahaan yang akan mencatatkan sahamnya di lantai bursa, direksi PT. BEJ mengeluarkan keputusan nomor Kep-339/BEJ/07-2001 tanggal 20 Juli 2001 yang berisi kewajiban mempunyai komisaris independen sekurang-kurangnya $30 \%$.

Beberapa peneliti telah melakukan penelitian mengenai jumlah dan komposisi dewan komisaris dalam hubungannya dengan kinerja keuangan perusahaan. Hermalin and Weisbach (2003), Coles et al. (2007), menemukan hubungan yang negatif antara jumlah dewan komisaris dengan kinerja perusahaan (dalam Pathan et al., 2007). Sedangkan Belkhir (2005), Kyereboah-Coleman and Biekpe (2006) menemukan bahwa hubungan yang positif antara jumlah dewan komisaris terhadap kinerja perusahaan.

Dari hasil penelitian yang dilakukan oleh Pathan et al. (2007), terbukti secara statistik terdapat hubungan positif dan signifikan antara jumlah komisaris independen terhadap kinerja keuangan perusahaan. Hal ini didukung oleh Metrick and Ishii (2002), Skully (2002), dan Kyereboah-Coleman and Biekpe (2006).

\section{B. Perumusan Masalah}

1. Bagaimana Jumlah Dewan Komisaris (Board Size) berpengaruh terhadap kinerja keuangan perusahaan?

2. Bagaimana Komposisi Dewan Komisaris (Board Composition) berpengaruh terhadap kinerja keuangan perusahaan?

3. Bagaimana Ukuran Perusahaan (Firm Size) berpengaruh terhadap kinerja keuangan perusahaan?

4. Bagaimana Non-Performing Loan (NPL) berpengaruh terhadap kinerja keuangan perusahaan? 
5. Bagaimana Financial Leverage berpengaruh terhadap kinerja keuangan perusahaan?

\section{Tujuan Penelitian}

1. Mengetahui Jumlah Dewan Komisaris (Board Size) berpengaruh terhadap kinerja keuangan perusahaan.

2. Mengetahui Komposisi Dewan Komisaris berpengaruh (Board Composition) terhadap kinerja keuangan perusahaan.

3. Mengetahui pengaruh Ukuran Perusahaan (Firm Size) berpengaruh terhadap kinerja keuangan perusahaan.

4. Mengetahui pengaruh Non-Performing Loan (NPL) berpengaruh terhadap kinerja keuangan perusahaan.

5. Mengetahui pengaruh Financial Leverage berpengaruh terhadap kinerja keuangan perusahaan

\section{Landasan Teori}

Dengan menganut sistem two-board system, maka kepengurusan perusahaan di Indonesia terbagi menjadi dua, yaitu dilakukan oleh Dewan Komisaris dan Direksi. Ada pemisahan yang tegas bagi keduanya dalam hal wewenang, tanggung jawab, dan fungsi masing-masing. Namun demikian mereka memiliki tanggung jawab yang sama dalam menjaga kesinambungan usaha perusahaan dalam jangka panjang.

Komite Nasional Kebijakan Governance (2006) mengatakan bahwa Dewan Komisaris merupakan organ perusahaan yang bertugas dan bertanggung jawab secara kolektif untuk melakukan pengawasan dan memberikan nasihat kepada Direksi serta memastikan bahwa perusahaan telah melakukan GCG. Namun demikian, Dewan Komisaris tidak boleh turut serta dalam mengambil keputusan operasional.

\subsection{Good Corporate Governance}

Menurut Peratuan Bank Indonesia nomor 8/14/PBI/2006 tentang perubahan atas Peraturan Bank Indonesia nomor 8/4/PBI/2006 tentang pelaksanaan GCG bagi bank umum, pada pasal 1 disebutkan bahwa Good Corporate Governance adalah suatu tata kelola bank yang menerapkan prinsip-prinsip keterbukaan (transparency), akuntabilitas (accountability), pertanggungjawaban (responsibility), independensi (independency), dan kewajaran (fairness).

\subsection{Stewardship dan Agency Theory}

Stewardship theory dibangun di atas asumsi filosofis mengenai sifat manusia yakni bahwa manusia pada hakekatnya dapat dipercaya, mampu bertindak dengan penuh tanggung jawab, memiliki integritas dan kejujuran kepada pihak lain. Inilah yang tersirat dalam hubungan fidusia yang dikehendaki pada pemegang saham. Dengan kata lain, stewardship theory memandang manajemen dapat dipercaya untuk bertindak dengan sebaik-baiknya bagi kepentingan publik pada umumnya, maupun shareholders pada khususnya (Daniri, 2005).

Stewardship menekankan manfaat pada shareholder return bila struktur otoritas bersifat fasilitatif melalui penyatuan pimpinan puncak manajemen (Chief Executive Officer/CEO) dengan pimpinan organ pengawasan (chairman / chair of the board). Peran 
ganda CEO dan Chairman ini diharapkan akan meningkatkan afektivitas dan hasil yang diperoleh, serta mengutamakan superior return kepada shareholders daripada pemisahan peran CEO dan Chairman.

Sementara itu, Agency theory menjelaskan hubungan kontraktual antara pihak yang mendelegasikan pengambilan keputusan tertentu (principal/pemilik/ pemegang saham) dengan pihak yang menerima pendelegasian tersebut (agen/direksi/manajemen). Agency theory memfokuskan pada penentuan kontrak yang paling efisien yang mempengaruhi hubungan prinsipal dan agen.

Agency theory memandang bahwa manajemen perusahaan sebagai agents bagi para pemegang saham, akan bertindak dengan penuh kesadaran bagi kepentingan sendiri, bukan sebagai pihak yang arif dan bijaksana serta adil terhadap pemegang saham sebagai sebagaimana diasumsikan dalam stewardship theory. Bertentangan dengan stewardship theory, agency theory memandang bahwa manajemen tidak dapat dipercaya untuk bertindak sebaik-baiknya bagi kepentingan publik pada umumnya, maupun shareholders pada khususnya. Dengan demikian, manajer tidak dapat dipercaya untuk melaksanakan tugas mereka dalam memaksimalkan shareholder value (Daniri, 2005).

\subsection{Kinerja Keuangan Perusahaan}

Kinerja merupakan hasil dari proses yang telah dilakukan oleh perusahaan. Kinerja keuangan dapat ditunjukkan dalam beberapa ukuran, antara lain berupa laba/keuntungan, efisiensi biaya, tingkat penjualan, dan lain sebagainya. Pengukuran kinerja keuangan perusahaan dapat dilakukan menggunakan beberapa rasio keuangan. Pathan et al. (2007) menggunakan rasio ROE (Return on Equity) dan ROA (Return on Assets) untuk mengukur kinerja keuangan bank-bank di Thailand. Bauer et al. (2004) mengukur kinerja perusahaan-perusahaan di Eropa menggunakan dua buah rasio, yaitu NPM (Net Profit Margin) dan ROA. Sedangkan Kyereboah-Coleman and Biekpe (2006), selain menggunakan ROA dan ROE; mereka juga menambahkan ukuran sales growth untuk mengukur kinerja perusahaan eksportir di Ghana.

Dalam bukunya, Rose and Hudgins (2005), menjelaskan bahwa ROE dan ROA merupakan rasio yang digunakan untuk mengukur kinerja perusahaan dalam hal profitabilitas pada saat ini. ROA merupakan indikator efisiensi manajerial yang mengindikasikan seberapa besar kemampuan manajemen bank dalam merubah atau menggunakan aset perusahaan menjadi pendapatan (earnings). Semakin besar ROA, maka berarti semakin besar keuntungan yang dicapai oleh bank tersebut, serta semakin baik posisinya dari sisi penggunaan assetnya.

Sementara itu, ROE mengukur rate of return flowing to the bank's shareholders. ROE merupakan perkiraan keuntungan bersih (net benefit) yang diterima stakeholders dari besarnya investasi modal yang telah mereka lakukan pada perusahaan. Rasio ini digunakan untuk mengukur tingkat kemampuan manajemen pada sebuah bank dalam mengelola modalnya sendiri, serta merupakan indikator keuangan yang sangat penting bagi para stakeholders untuk mengukur kemampuan bank tersebut dalam menghasilkan laba bersih. Apabila ROE meningkat, maka berarti laba bersih yang mampu dihasilkan oleh bank tersebut juga meningkat. Rumus untuk ROE dan ROA tersebut adalah sebagai berikut: 


$$
\begin{aligned}
& \mathrm{ROE}=\frac{\text { Net income after tax }}{\text { Total } \text { equity capital }} \times 100 \% \\
& \mathrm{ROA}=\frac{\text { Net income after } \text { tax }}{\text { Total assets }} \times 100 \%
\end{aligned}
$$

\subsection{Jumlah Dewan Komisaris dan Kinerja}

Jumlah dewan komisaris merupakan jumlah individu dalam dewan komisaris suatu perusahaan. Terdapat beberapa hal yang menyebutkan hubungan antara jumlah dewan komisaris terhadap kinerja perusahaan. Beberapa hal tersebut antara lain (dalam Pathan et al., 2007):

a. Small boards are considered effective and value additive because of their nimbleness and cohesiveness together with the perception that they require less communication and less costs spent on coordination. As well, they attract a lower degree of 'freeriding' director problems (Lipton and Lorsch, 1992; Jensen, 1993; Coles et al., 2007)

b. Directors in large boards may face greater difficulties in expressing their ideas and opinions in the limited time available at board meetings (Lipton and Lorsch;1992,p.65).

c. Moreover, since an individual board member's incentive to acquire information and to exert effort in monitoring managers is low in large boards, CEOs may find large boards easier to control (Jensen;1993,p.865).

Dari beberapa poin diatas, dapat kita ketahui bahwa jumlah komisaris berbanding terbalik dengan kinerja yang akan dihasilkan. Jumlah yang kecil ternyata lebih efektif, lebih bernilai tambah, komunikasi dan koordinasi antar anggota dewan menjadi lebih baik, dan menjadi tidak mudah untuk dikendalikan oleh direktur perusahaan.

Jumlah dewan komisaris juga telah mendapat perhatian dari pemerintah Indonesia, dengan diterbitkannya beberapa peraturan mengenai jumlah anggota dewan komisaris yang harus ada pada setiap perusahaan, yaitu antara lain:

a. UU No 40 Tahun 2007 tentang Perseroan Terbatas Pasal 108

Dewan Komisaris terdiri atas 1 (satu) orang anggota atau lebih. Dewan Komisaris yang terdiri atas lebih dari 1 (satu) orang anggota merupakan majelis dan setiap anggota Dewan Komisaris tidak dapat bertindak sendiri-sendiri, melainkan berdasarkan keputusan Dewan Komisaris. Perseroan yang kegiatan usahanya berkaitan dengan menghimpun dan/atau mengelola dana masyarakat, Perseroan yang menerbitkan surat pengakuan utang kepada masyarakat atau Perseroan Terbuka wajib mempunyai paling sedikit 2 (dua) orang anggota Dewan Komisaris.

b. Peraturan Bank Indonesia No. 8/14/PBI/2006 Pasal 4

Jumlah anggota dewan Komisaris paling kurang 3 (tiga) orang dan paling banyak sama dengan jumlah anggota Direksi. Paling kurang 1 (satu) orang anggota dewan Komisaris wajib berdomisili di Indonesia. Dewan Komisaris dipimpin oleh Presiden Komisaris atau Komisaris Utama.

\subsection{Jumlah Komisaris Independen dan Kinerja}

Selain diharapkan mampu mencegah konflik keagenan, dengan melakukan fungsi pengawasannya, komisaris independen diharapkan mampu memberikan kontribusi bagi 
kinerja keuangan perusahaan. Keterkaitan antara komisaris independen dengan kinerja perusahaan ditunjukkan oleh beberapa hal berikut ini:

a. According to agency theory, outside directors perform better in monitoring managerial activities (Fama, 1980, dalam Lam and Lee, 2008).

b. While a higher proportion of outside directors on the board enhance its monitoring effectiveness (Fama and Jensen, 1983, dalam Lam and Lee, 2008).

c. Independent directors have more incentives to protect shareholders interest because they consider that maintaining their 'reputation' in the market for outside directorships to be important (Fama, 1980; Fama and Jensen, 1983; Farrell and Whidbee, 2000; dalam Pathan et al. 2007).

d. Independent/outside directors protect shareholders' interest in specific instancessuch as reducing the possibility of a hostile takeover (Shivdasani 1993, dalam Pathan et al. 2007).

e. Independent / outside directors providing more return to the target firms (Cotter et al. 1997, dalam Pathan et al. 2007).

Dari kelima poin diatas, secara garis besar dapat dikatakan bahwa dengan adanya komisaris independen maka fungsi pengawasan komisaris akan berjalan lebih efektif. Dengan begitu maka kepentingan shareholder dapat terjaga dengan baik. Selain itu, adanya komisaris independen ternyata dapat juga menambah return perusahaan.

Terjadinya reformasi GCG diseluruh negara terkait pentingnya komisaris yang independen dalam dewan komisaris menarik perhatian pemerintah (regulator) untuk mempertimbangkan adanya komisaris independen untuk mencapai fungsi pengawasan yang lebih baik.

Untuk perusahaan yang akan mencatatkan sahamnya di lantai bursa, pemerintah melalui Keputusan Direksi PT. BEJ mengeluarkan keputusan nomor Kep-339/BEJ/072001 tanggal 20 Juli 2001, yang menyatakan bahwa salah satu syarat calon Perusahaan Tercatat baik yang akan mencatatkan saham di papan utama maupun di papan pengembangan wajib memiliki komisaris independen sekurang-kurangnya $30 \%$ (tiga puluh perseratus) dari jajaran anggota dewan komisaris yang dapat dipilih terlebih dahulu melalui RUPS sebelum pencatatan dan mulai efektif bertindak sebagai komisaris setelah saham perusahaan tersebut tercatat.

Sedangkan untuk perusahaan perbankan baru diatur oleh Bank Indonesia pada Tahun 2006, dengan peraturan sebagai berikut:

a. Peraturan Bank Indonesia No. 8/14/PBI/2006. Pasal 5

Dewan Komisaris terdiri dari Komisaris dan Komisaris Independen. Paling kurang 50\% (lima puluh perseratus) dari jumlah anggota dewan Komisaris adalah Komisaris Independen.

b. Surat Edaran Bank Indonesia No. 9/12/DPNP tanggal 30 Mei 2007 perihal Pelaksanaan Good Corporate Governance bagi Bank Umum

Komisaris Independen ditetapkan paling kurang 50\% (lima puluh perseratus) dari jumlah anggota Dewan Komisaris. Yang dimaksud dengan Komisaris Independen adalah anggota Dewan Komisaris yang tidak memiliki hubungan keuangan, kepengurusan, kepemilikan saham, dan/atau hubungan keluarga dengan anggota Dewan Komisaris lainnya, Direksi dan/atau Pemegang Saham Pengendali atau hubungan dengan Bank, yang dapat mempengaruhi kemampuannya untuk bertindak independen. 
Komposisi Dewan Komisaris (KDK) yang merupakan perbandingan antara komisaris independen terhadap total komisaris dirumuskan sebagai berikut:

$$
\mathrm{KDK}=\frac{\text { Jumlah Komisaris Independen }}{\text { Jumlah selum anggota komisaris }} \times 100 \%
$$

\subsection{Tugas Dewan Komisaris}

Dalam melaksanakan tugasnya, selain berdasarkan ketentuan masing-masing perusahaan, beberapa tugas dewan komisaris juga diatur dalam perundangan berikut ini:

a. UU No 40 Tahun 2007 tentang Perseroan Terbatas Pasal 108

Dewan Komisaris melakukan pengawasan atas kebijakan pengurusan, jalannya pengurusan pada umumnya, baik mengenai Perseroan maupun usaha Perseroan, dan memberi nasihat kepada Direksi. Pengawasan dan pemberian nasihat sebagaimana dimaksud dilakukan untuk kepentingan Perseroan dan sesuai dengan maksud dan tujuan Perseroan.

b. Peraturan Bank Indonesia No. 8/14/PBI/2006 Pasal 9

1) Dewan Komisaris wajib memastikan terselenggaranya pelaksanaan Good Corporate Governance dalam setiap kegiatan usaha Bank pada seluruh tingkatan atau jenjang organisasi sebagaimana dimaksud dalam Pasal 2.

2) Dewan Komisaris wajib melaksanakan pengawasan terhadap pelaksanaan tugas dan tanggung jawab Direksi, serta memberikan nasihat kepada Direksi.

3) Dalam melakukan pengawasan sebagaimana dimaksud pada ayat (2), Komisaris wajib mengarahkan, memantau, dan mengevaluasi pelaksanaan kebijakan strategis Bank.

4) Dalam melakukan pengawasan sebagaimana dimaksud pada ayat (2), dewan Komisaris dilarang terlibat dalam pengambilan keputusan kegiatan operasional Bank, kecuali :

a. penyediaan dana kepada pihak terkait sebagaimana diatur dalam ketentuan Bank Indonesia tentang Batas Maksimum Pemberian Kredit Bank Umum; dan

b. hal-hal lain yang ditetapkan dalam Anggaran Dasar Bank atau peraturan perundangan yang berlaku.

5) Pengambilan keputusan oleh dewan Komisaris sebagaimana dimaksud pada ayat (4), merupakan bagian dari tugas pengawasan oleh Komisaris sehingga tidak meniadakan tanggung jawab Direksi atas pelaksanaan kepengurusan Bank.

c. Peraturan Bank Indonesia No. 8/14/PBI/2006, Pasal 10

Dewan Komisaris wajib memastikan bahwa Direksi telah menindaklanjuti temuan audit dan rekomendasi dari satuan kerja audit intern Bank, auditor eksternal, hasil pengawasan Bank Indonesia dan/atau hasil pengawasan otoritas lain.

\subsection{Ukuran Perusahaan}

Ukuran (size) atau besarnya perusahaan diukur dengan besarnya nilai aktiva secara keseluruhan atau total aset perusahaan. Ukuran yang dipakai dalam menentukan besarnya perusahaan adalah total aktiva. Semakin besar total aktiva perusahaan maka semakin besar pula risiko yang dimiliki perusahaan tersebut karena perusahaan akan menghadapi tantangan yang lebih besar dalam mengelola aktivanya dibandingkan 
dengan perusahaan yang memiliki total aktiva yang lebih kecil. Dengan aktiva yang besar dan pengelolaan yang baik akan membuat perusahaan mampu menambah keuntungannya sehingga kinerja akan meningkat. Dalam penelitian yang dilakukan Pathan et al., (2007), didapati bahwa ukuran bank memiliki hubungan yang positif dan signifikan padal level $5 \%$ terhadap ROA dan ROE

Dikarenakan perusahaan sampel memiliki variasi aset yang beragam dan dalam jumlah yang besar, maka digunakan ukuran log untuk merumuskan ukuran perusahaan. Sehingga dalam menghitung ukuran perusahaan digunakanlah rumus:

$$
\text { Size }=\text { Log Total Aktiva }
$$

\subsection{Non Performing Loan (NPL)}

Non Performing Loan (NPL) terkait dengan berkurangnya kemampuan debitur (peminjam) dalam memenuhi kewajibannya (baik pokok maupun bunga) dalam periode waktu tertentu. Tingkat kolektibilitas kredit dikategorikan menjadi lima golongan, yaitu kredit lancar, dalam perhatian khusus, kurang lancar, diragukan, dan macet. Yang termasuk sebagai non performing adalah tiga golongan terakhir. Rasio NPL terkait dengan kemampuan likuiditas bank. Semakin tinggi rasio ini menunjukkan bahwa bank tersebut mengalami kesulitan likuiditas. Untuk itu Bank Indonesia menetapkan batas maksimal rasio ini sebesar 5\%. Apabila suatu bank mempunyai NPL lebih dari 5\% maka akan masuk dalam pengawasan Bank Indonesia.

Selain itu, perbankan diwajibkan untuk membuat pencadangan apabila kredit yang diberikannya berada pada golongan selain lancar. Besarnya pencadangan berbeda setiap golongan dengan semakin buruk kualitas kreditnya maka akan semakin besar pula pencadangan yang harus dibuat dan pencadangan ini diambilkan dari beban / biaya perusahaan. Hal ini akan secara langsung mempengaruhi kinerja keuangan perusahaan.

Dalam penelitian yang dilakukannya pada perbankan Thailand, Pathan et al. (2007) menemukan hubungan yang negatif antara besarnya NPL dengan ROA dan ROE.

$$
\mathrm{NPL}=\frac{\text { Non }- \text { Performing Loans }}{\text { Gross Loans }} \times 100 \%
$$

\subsection{Financial leverage}

Financial leverage mengacu pada penggunaan hutang (debt) dengan harapan diperolehnya keuntungan melebihi biaya hutangnya, dengan begitu hal ini dapat meningkatkan potensial return stockholders dan financial leverage juga menunjukkan penggunaan utang dalam rangka pembiayaan perusahaan. Financial leverage timbul karena adanya kewajiban finansial yang sifatnya tetap (fixed financial charges) yang harus dikeluarkan oleh perusahaan. Semakin besar hutang yang dimiliki tentu saja membuat perusahaan harus menyisihkan keuntungannya secara tetap untuk membayar kewajibannya, baik pokok maupun bunga. Apabila tidak dikelola dengan baik, bisa saja terjadi lebih besar kewajiban yang harus dikeluarkan perusahaan dibandingkan dengan pendapatan dari penggunaan hutang tersebut. Hal ini akan menimbulkan kerugian bagi perusahaan. Tetapi akan terjadi sebaliknya bila hutang tersebut dikelola dengan baik. 
Rasio leverage menunjukkan bagaimana aset perusahaan tersebut dibiayai, baik dengan utang atau modal sendiri. Pathan et al., (2007) menemukan bahwa leverage berhubungan negatif dengan kinerja bank. Menurut Rose and Hudgins (2005) rasio tersebut dirumuskan sebagai berikut:

Financial Leverage $=X 100 \%$

\section{E. Metodologi}

Mengacu pada penelitian Pathan et al., (2007) dan dan Kyereboah-Coleman and Biekpe (2006), penelitian ini bertujuan untuk mengetahui apakah terdapat pengaruh komposisi dewan komisaris terhadap kinerja perusahaan. Penelitian ini melibatkan variabel-variabel berikut. (1) Variabel terikat (dependent variabel) yaitu Jumlah Dewan Komisaris, Komposisi Dewan Komisaris, Ukuran Perusahaan, Non-performing Loans (NPL), dan Financial Leverage, dan (2) Variabel bebas (independent variable) yang terdiri dari oleh Return On Equity (ROE) dan Return On Assets (ROA).

Populasi dan sampel yang digunakan adalah perusahaan sektor perbankan yang telah terdaftar di Bursa Efek Indonesia secara terus menerus selama periode 2003 2007, mempublikasikan laporan keuangan tahunan untuk periode 31 Desember 2003 2007 yang dinyatakan dalam rupiah, dan data yang tersedia lengkap (data secara keseluruhan tersedia pada publikasi periode 31 Desember 2003-2007).

Metode penelitian yang digunakan dalam penelitian ini adalah metode deskriptif dilihat dari nilai rata-rata (mean), standar deviasi, minimum, dan maksimum. Pengujian asumsi klasik yang dilakukan terdiri atas uji normalitas, uji multikolinearitas, uji autokorelasi, dan uji heteroskedastisitas. Uji Regresi Linier Berganda, Uji Koefisien Determinasi, dan Uji Hipotesis.

\section{F. Hasil dan Pembahasan}

Data yang digunakan dalam penelitian ini merupakan data sekunder dari perusahaan perbankan yang terdaftar di Bursa Efek Indonesia. Pengolahan data dilakukan dengan menggunakan program pengolah data statistik, yakni SPSS Ver.17.0.

Dari kriteria yang telah disebutkan pada bab sebelumnya didapat 22 perusahaan perbankan yang dapat digunakan sebagai sampel penelitian, dengan rincian sebagai berikut:

\begin{tabular}{|c|l|l|}
\hline NO & KODE & \multicolumn{1}{|c|}{ NAMA BANK } \\
\hline 1 & BABP & Bank Bumiputera Indonesia \\
\hline 2 & BBCA & Bank Central Asia \\
\hline 3 & BBIA & Bank Buana Indonesia \\
\hline 4 & BBNI & Bank Negara Indonesia \\
\hline 5 & BBNP & Bank Nusantara Parahyangan \\
\hline 6 & BBRI & Bank Rakyat Indonesia \\
\hline 7 & BCIC & Bank Century \\
\hline 8 & BDMN & Bank Danamon Indonesia \\
\hline 9 & BEKS & Bank Eksekutif Internasional \\
\hline 10 & BKSW & Bank Kesawan \\
\hline 11 & BMRI & Bank Mandiri \\
\hline
\end{tabular}

\begin{tabular}{|c|l|l|}
\hline NO & KODE & \multicolumn{1}{|c|}{ NAMA BANK } \\
\hline 12 & BNGA & Bank Niaga \\
\hline 13 & BNII & Bank Internasional Indonesia \\
\hline 14 & BNLI & Bank Permata \\
\hline 15 & BSWD & Bank Swadesi \\
\hline 16 & BVIC & Bank Victoria International \\
\hline 17 & INPC & Bank Inter-Pacififc \\
\hline 18 & LPBN & Bank Lippo \\
\hline 19 & MAYA & Bank Mayapada Internasional \\
\hline 20 & MEGA & Bank Mega \\
\hline 21 & NISP & Bank NISP \\
\hline 22 & PNBN & Bank Pan Indonesia \\
\hline
\end{tabular}




\section{Uji Asumsi Klasik}

a. Uji Normalitas

Untuk mendeteksi apakah residual terdistribusi normal atau tidak akan dilakukan pengujian non parametrik Kolmogorov-Smirnov.

Tabel 6.1

\section{Uji Normalitas dengan Kolmogorov-Smirnov}

One-Sample Kolmogorov-Smirnov Test

\begin{tabular}{|ll|r|r|}
\hline & & ROE & \multicolumn{1}{c|}{ ROA } \\
\hline N & & 107 & 107 \\
Normal Parameters ${ }^{\mathrm{a}, \mathrm{D}}$ & Mean & 15.5362 & 1.9025 \\
& Std. Deviation & 13.27424 & 1.45613 \\
Most Extreme Differences & Absolute & .110 & .095 \\
& Positive & .110 & .095 \\
& Negative & -.097 & -.089 \\
Kolmogorov-Smirnov Z & & 1.141 & .981 \\
Asymp. Sig. (2-tailed) & & .148 & .291 \\
\hline
\end{tabular}

a. Test distribution is Normal.

b. Calculated from data.

Sumber : Data diolah menggunakan SPSS 17.0

Dari tabel 6.1 diatas diketahui bahwa nilai probalilitas ROE dan ROA [Asymp. Sig. (2-tailed)] diatas tingkat signifikansi, yakni 0,148>0.05 dan 0,291 >0,05. Ini berarti model regresi telah memenuhi asumsi normalitas, dimana data berdistribusi normal.

\section{b. Uji Multikolonieritas}

Untuk mengetahui ada tidaknya multikolinieritas adalah dengan melihat nilai Variance Inflation Factors (VIF) atau Tolerance value (TOL). Jika nilai VIF $<5$ dan nilai TOL mendekati 1 maka tidak terdapat multikolinieritas antar variabel bebas

Tabel 6.2

Uji Multikolonieritas

Coefficients $^{a}$

\begin{tabular}{|c|c|c|c|c|c|c|c|c|}
\hline \multirow{2}{*}{\multicolumn{2}{|c|}{ Model }} & \multicolumn{2}{|c|}{$\begin{array}{c}\text { Unstandardized } \\
\text { Coefficients }\end{array}$} & \multirow{2}{*}{$\begin{array}{c}\begin{array}{c}\text { Standardized } \\
\text { Coefficients }\end{array} \\
\text { Beta }\end{array}$} & \multirow[b]{2}{*}{$\mathrm{t}$} & \multirow[b]{2}{*}{ Sig. } & \multicolumn{2}{|c|}{ Collinearity Statistics } \\
\hline & & B & Std. Error & & & & Tolerance & VIF \\
\hline 1 & (Constant) & 12.141 & 2.915 & & 4.165 & .000 & & \\
\hline & JDK & -.121 & .054 & -.195 & -2.236 & .028 & .634 & 1.576 \\
\hline & KDK & -.001 & .008 & -.009 & -.127 & 899 & .959 & 1.043 \\
\hline & SIZE & 1.080 & .176 & .540 & 6.153 & .000 & .628 & 1.592 \\
\hline & LEV & -.184 & .029 & -.440 & -6.276 & .000 & .988 & 1.012 \\
\hline & NPL & -.145 & .027 & -.380 & -5.370 & .000 & .970 & 1.031 \\
\hline
\end{tabular}

a. Dependent Variable: ROA 
Tabel 6.3

Uji Multikolonieritas

Coefficients $^{a}$

\begin{tabular}{|c|c|c|c|c|c|c|c|c|}
\hline \multirow{2}{*}{\multicolumn{2}{|c|}{ Model }} & \multicolumn{2}{|c|}{$\begin{array}{l}\text { Unstandardized } \\
\text { Coefficients }\end{array}$} & \multirow{2}{*}{$\begin{array}{c}\text { Standardized } \\
\text { Coefficients }\end{array}$} & \multirow[b]{2}{*}{$\mathrm{t}$} & \multirow[b]{2}{*}{ Sig. } & \multicolumn{2}{|c|}{ Collinearity Statistics } \\
\hline & & $\mathrm{B}$ & Std. Error & & & & Tolerance & VIF \\
\hline \multirow[t]{6}{*}{1} & (Constant) & -16.084 & 31.850 & & -.505 & .615 & & \\
\hline & JDK & -.856 & .589 & -.152 & -1.453 & .149 & .634 & 1.576 \\
\hline & KDK & -.131 & .089 & -.125 & -1.466 & .146 & .959 & 1.043 \\
\hline & SIZE & 10.430 & 1.918 & .572 & 5.437 & .000 & .628 & 1.592 \\
\hline & LEV & -.317 & .321 & -.083 & -.988 & .325 & .988 & 1.012 \\
\hline & NPL & -.860 & .295 & -.247 & -2.917 & .004 & .970 & 1.031 \\
\hline
\end{tabular}

a. Dependent Variable: $\mathrm{ROE}$

Tabel 6.2 dan 6.3 diatas menunjukan bahwa semua nilai tolerance mendekati 1 dan semua nilai VIF berada dibawah 5. Dari hasil pengujian ini dapat disimpulkan bahwa tidak ada multikolinieritas dalam persamaan regresi yang digunakan dalam penelitian

\section{c. Uji Autokorelasi}

Autokorelasi merupakan keadaan dimana kesalahan pengganggu saling berkorelasi. Pengujian ini bertujuan untuk melihat apakah terdapat korelasi antara kesalahan pada periode t dengan kesalahan pada periode t-1 (sebelumnya) pada sebuah model regresi. Jika terjadi korelasi, maka dinamakan ada problem autokorelasi.

Untuk mendeteksi autokorelasi digunakan uji Durbin-Watson. Untuk memenuhi kriteria tidak terdapat autokorelasi, nilai DW harus lebih besar dari dU dan lebih kecil dari 4-dU. Berdasarkan data pengujian, untuk $n=107$ dan $k=5$ pada tingkat signifikansi 0,05 , dari tabel $\mathrm{DW}$ diperoleh nilai $\mathrm{dL}=1,751$ dan nilai $\mathrm{dU}=1,780$.

Tabel 6.4

Model Summary

\begin{tabular}{|l|r|r|r|r|r|}
\hline Model & $\mathrm{R}$ & R Square & \multicolumn{1}{|c|}{$\begin{array}{c}\text { Adjusted R } \\
\text { Square }\end{array}$} & $\begin{array}{c}\text { Std. Error of the } \\
\text { Estimate }\end{array}$ & Durbin-Watson \\
\hline 1 & $.714^{\mathrm{a}}$ & .510 & .486 & 1.04369 & 1.805 \\
\hline
\end{tabular}

a. Predictors: (Constant), NPL, LEV, JDK, KDK, SIZE

b. Dependent Variable: ROA

Tabel 6.5

Model Summary

\begin{tabular}{|r|r|r|r|r|r|}
\hline Model & \multicolumn{1}{|c|}{$\mathrm{R}$} & R Square & $\begin{array}{c}\text { Adjusted R } \\
\text { Square }\end{array}$ & $\begin{array}{c}\text { Std. Error of the } \\
\text { Estimate }\end{array}$ & Durbin-Watson \\
\hline 1 & $.545^{\mathrm{a}}$ & .297 & .262 & 11.40478 & 1.816 \\
\hline
\end{tabular}

a. Predictors: (Constant), NPL, LEV, JDK, KDK, SIZE

b. Dependent Variable: ROE

Dari data dL dan dU serta nilai DW dari hasil pengujian pada Tabel 6.4 dan 6.5 diatas, dapat diketahui bahwa model regresi tidak terdapat autokorelasi. Hasil pengujian tersebut dapat ditunjukkan pada gambar 6.1 berikut: 
Gambar 6.1

Hasil Uji Autokorelasi

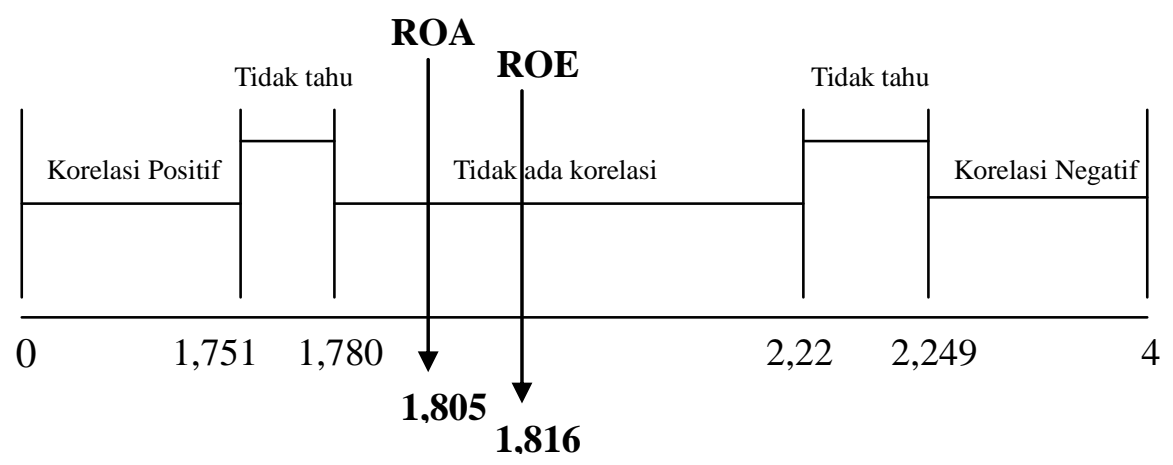

\section{d. Uji Heteroskedastisitas}

Uji heteroskedastisitas bertujuan untuk menguji apakah dalam model regresi terjadi ketidaksamaan varians dari residual satu pengamatan ke pengamatan lain. Jika varians residual dari satu pengamatan ke pengamatan lain berbeda maka disebut heterokedastisitas. Cara yang digunakan untuk mendeteksi gejala heterokedastisitas dalam penelitian ini adalah dengan menggunakan uji White. Jika hasil perkalian nilai n.R2 $\geq$ tabel $x 2$, maka terjadi masalah heteroskedastisitas. Sebaliknya bila nilai $n . R 2<$ tabel $x 2$, maka tidak terjadi heteroskedastisitas.

Tabel 6.6

\begin{tabular}{|l|r|r|r|c|}
\multicolumn{6}{c|}{ Model Summary } \\
\hline Model & $\mathrm{R}$ & R Square & $\begin{array}{c}\text { Adjusted R } \\
\text { Square }\end{array}$ & $\begin{array}{c}\text { Std. Error of the } \\
\text { Estimate }\end{array}$ \\
\hline 1 & $.505^{\mathrm{a}}$ & .255 & .082 & 1.919102 \\
\hline
\end{tabular}

a. Predictors: (Constant), LEV_NPL, JDK, LEV, KDK, SIZE_2, NPL_2, JDK_KDK, JDK_NPL, KDK_NPL, JDK_2, KDK_2, SIZE_NPL,

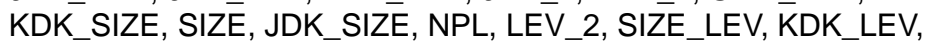
JDK_LEV

\section{Tabel 6.7}

ANOVA $^{\text {D }}$

\begin{tabular}{|ll|r|r|r|r|r|}
\hline Model & Sum of Squares & \multicolumn{1}{|c|}{ df } & Mean Square & F & \multicolumn{1}{c|}{ Sig. } \\
\hline 1 & Regression & 108.423 & 20 & 5.421 & 1.472 & $.113^{\mathrm{a}}$ \\
& Residual & 316.734 & 86 & 3.683 & & \\
& Total & 425.157 & 106 & & & \\
\hline
\end{tabular}

a. Predictors: (Constant), LEV_NPL, JDK, LEV, KDK, SIZE 2, NPL 2, JDK KDK, JDK NPL, KDK_NPL, JDK_2, KDK_2, SIZZE_NPL, KDK_SIZE, SIZE, JDK_SIZE, NPL, LEV_2, SIZ̄E_LEV, KDK_LEV, JDK_LEV

b. Dependent Variable: RES_ROA_2

Tabel 6.6 dan 6.7 diatas merupakah hasil perhitungan dengan residual ROA kuadrat sebagai variabel dependen. Dari Tabel 6.6 diketahui nilai adjusted $\mathrm{R}^{2}$ sebesar 0,082 , sehingga nilai $n \cdot R^{2}=107 \times 0,082=8,744$. Dengan tingkat signifikansi 0,05 dan df 
$=20$ (pada Tabel 6.7), diperoleh nilai tabel $x^{2}$ sebesar 31,4104 . Sehingga nilai $n \cdot R^{2}$ lebih kecil tabel $x^{2}(8,744<31,404)$. Ini berarti tidak terdapat masalah heterokedastisitas dalam model statistik.

Tabel 6.8

\begin{tabular}{|l|r|r|r|c|}
\multicolumn{5}{c|}{ Model Summary } \\
\hline Model & $\mathrm{R}$ & R Square & $\begin{array}{c}\text { Adjusted R } \\
\text { Square }\end{array}$ & $\begin{array}{c}\text { Std. Error of the } \\
\text { Estimate }\end{array}$ \\
\hline 1 & $.631^{\mathrm{a}}$ & .398 & .258 & 307.868328 \\
\hline
\end{tabular}

a. Predictors: (Constant), LEV NPL, JDK, LEV, KDK, SIZE 2, NPL 2, JDK_KDK, JDK_NPL, KDK_NPL, JDK_2, KDK_2, SIZE_NPL, KDK_SIZE, SIZE, JDK_SIZE, NPL, LEV_2, SIZE_LEV, KDK_LEV, JDK_LEV

Tabel 6.9

ANOVA $^{\mathrm{D}}$

\begin{tabular}{|ll|r|r|r|r|r|}
\hline Model & & Sum of Squares & \multicolumn{1}{|c|}{ df } & Mean Square & \multicolumn{1}{c|}{$\mathrm{F}$} & \multicolumn{1}{c|}{ Sig. } \\
\hline 1 & Regression & 5397314.295 & 20 & 269865.715 & 2.847 & $.000^{\mathrm{a}}$ \\
& Residual & 8151330.053 & 86 & 94782.908 & & \\
& Total & $1.355 \mathrm{E} 7$ & 106 & & & \\
\end{tabular}

a. Predictors: (Constant), LEV NPL, JDK, LEV, KDK, SIZE 2, NPL 2, JDK KDK, JDK NPL, KDK_NPL, JDK_2, KDK_2, SIZE_NPL, KDK_SIZE, SIZE, JDK_SIZE, NPL, LEV_2, SIZEELLEV, KDK_LEV, JDK_LEV

b. Dependent Variable: RES_ROE_2

Tabel 6.8 dan 6.9 diatas merupakan hasil perhitungan dengan residual $\mathrm{ROE}$ kuadrat sebagai variabel dependen. Dari Tabel 6.8 diketahui nilai adjusted $\mathrm{R}^{2}$ sebesar 0,258 , sehingga nilai $n \cdot R^{2}=107 \times 0,258=27,606$. Dengan tingkat signifikansi 0,05 dan df $=20$ (pada Tabel 6.9), diperoleh nilai tabel $x^{2}$ sebesar 31,4104. Sehingga nilai $n \cdot R^{2}$ lebih kecil tabel $x^{2}(27,606<31,404)$. Ini berarti tidak terdapat masalah heterokedastisitas dalam model statistik.

\section{Regresi Linier Berganda}

Dengan menggunakan SPSS 17.0 diperoleh hasil perhitungan regresi berganda sebagai berikut:

Tabel 6.10

Coefficients $^{\mathrm{a}}$

\begin{tabular}{|c|c|c|c|c|c|c|}
\hline \multirow{2}{*}{\multicolumn{2}{|c|}{ Model }} & \multicolumn{2}{|c|}{$\begin{array}{l}\text { Unstandardized } \\
\text { Coefficients }\end{array}$} & \multirow{2}{*}{$\begin{array}{c}\text { Standardized } \\
\text { Coefficients }\end{array}$} & \multirow[b]{2}{*}{$\mathrm{t}$} & \multirow[b]{2}{*}{ Sig. } \\
\hline & & B & Std. Error & & & \\
\hline \multirow[t]{6}{*}{1} & (Constant) & 12.141 & 2.915 & & 4.165 & .000 \\
\hline & JDK & -.121 & .054 & -.195 & -2.236 & .028 \\
\hline & KDK & -.001 & .008 & -.009 & -.127 & .899 \\
\hline & SIZE & 1.080 & .176 & .540 & 6.153 & .000 \\
\hline & LEV & -.184 & .029 & -.440 & -6.276 & .000 \\
\hline & NPL & -.145 & .027 & -.380 & -5.370 & .000 \\
\hline
\end{tabular}


Coefficients $^{\mathrm{a}}$

\begin{tabular}{|c|c|c|c|c|c|c|}
\hline \multirow{2}{*}{\multicolumn{2}{|c|}{ Model }} & \multicolumn{2}{|c|}{$\begin{array}{c}\text { Unstandardized } \\
\text { Coefficients }\end{array}$} & \multirow{2}{*}{$\begin{array}{c}\text { Standardized } \\
\text { Coefficients }\end{array}$} & \multirow[b]{2}{*}{$t$} & \multirow[b]{2}{*}{ Sig. } \\
\hline & & $B$ & Std. Error & & & \\
\hline \multirow[t]{6}{*}{1} & (Constant) & 12.141 & 2.915 & & 4.165 & .000 \\
\hline & JDK & -.121 & .054 & -.195 & -2.236 & .028 \\
\hline & KDK & -.001 & .008 & -.009 & -.127 & .899 \\
\hline & SIZE & 1.080 & .176 & .540 & 6.153 & .000 \\
\hline & LEV & -.184 & .029 & -.440 & -6.276 & .000 \\
\hline & NPL & -.145 & .027 & -.380 & -5.370 & .000 \\
\hline
\end{tabular}

a. Dependent Variable: ROA

Tabel 6.11

Coefficients $^{\mathrm{a}}$

\begin{tabular}{|ll|r|r|r|r|r|}
\hline \multirow{2}{*}{ Model } & \multicolumn{2}{|c|}{$\begin{array}{c}\text { Unstandardized } \\
\text { Coefficients }\end{array}$} & $\begin{array}{c}\text { Standardized } \\
\text { Coefficients }\end{array}$ & & \\
\cline { 2 - 4 } & \multicolumn{1}{|c|}{$\mathrm{B}$} & \multicolumn{1}{c|}{ Std. Error } & \multicolumn{1}{c|}{ Beta } & \multicolumn{1}{c|}{$\mathrm{t}$} & \multicolumn{1}{c|}{ Sig. } \\
\hline 1 & (Constant) & -16.084 & 31.850 & & -.505 & .615 \\
& JDK & -.856 & .589 & -.152 & -1.453 & .149 \\
& KDK & -.131 & .089 & -.125 & -1.466 & .146 \\
& SIZE & 10.430 & 1.918 & .572 & 5.437 & .000 \\
& LEV & -.317 & .321 & -.083 & -.988 & .325 \\
& NPL & -.860 & .295 & -.247 & -2.917 & .004 \\
\hline
\end{tabular}

a. Dependent Variable: ROE

Dari tabel 6.10 dan 6.11 diatas diperoleh persamaan regresi berikut ini:

$Y_{i t}=\alpha_{0}+\alpha_{1} J D K_{i t}+\alpha_{2} K D K_{i t}+\alpha_{3} S Z_{i t}+\alpha_{4} N P L_{i t}+\alpha_{5} L E V_{i t}+e_{i}$

$\mathrm{ROA}=12,141-0,121 \cdot \mathrm{JDK}-0,001 \cdot \mathrm{KDK}+1,080 \cdot \mathrm{SIZE}-0,184 \cdot \mathrm{NPL}-0,145 \cdot \mathrm{LEV}$

$\mathrm{ROE}=-16,084-0,856 \cdot \mathrm{JDK}-0,131 \cdot \mathrm{KDK}+10,430 \cdot \mathrm{SIZE}-0,317 \cdot \mathrm{NPL}-0,860 \cdot \mathrm{LEV}$

Dari kedua model regresi tersebut, maka didapatkan nilai $\alpha$ (intercept) sebesar 12,141 dan $-16,084$. Hal ini dapat dijelaskan bahwa jika tidak ada variabel jumlah dewan komisaris, komposisi dewan komisaris, ukuran perusahaan, non-performing loan, dan financial leverage, maka besaran ROA adalah sebesar 12,141 dan ROE sebesar 16,084 .

Koefisien regresi JDK sebesar -0.121 dan $-0,856$ berarti setiap peningkatan variabel JDK satu satuan maka akan menurunkan ROA sebesar 0.121 satuan, ceteris paribus; dan jika JDK naik satu satuan maka ROE akan turun sebesar 0,856 satuan. Dengan berhubungan negatif berarti setiap terjadi peningkatan jumlah dewan komisaris maka akan menurunkan kinerja keuangan perusahaan (ROA dan ROE). 
Koefisien regresi KDK sebesar -0.001 dan $-0,131$ berarti setiap peningkatan variabel JDK satu satuan maka akan menurunkan ROA sebesar 0.001 satuan, ceteris paribus; dan jika KDK naik satu satuan mala ROE akan turun sebesar 0,131 satuan. Sama seperti jumlah dewan komisaris, maka ini berarti setiap peningkatan komposisi dewan komisaris akan menurunkan kinerja keuangan perusahaan (ROA dan ROE).

Dari tabel 6.10 dan 6.11 diatas dapat ditarik kesimpulan pula bahwa:

a. Pada Tabel 6.10 memperlihatkan bahwa nilai dari probabilitas variabel JDK sebesar 0,028 atau lebih kecil dari nilai signifikansi $(0,05)$. Ini berarti Ho1 ditolak, sehingga dapat dikatakan bahwa jumlah dewan komisaris tidak berpengaruh negatif signifikan terhadap ROA. Pada Tabel 6.11 terlihat hasil regresi yang menunjukkan bahwa nilai probabilitas variabel JDK sebesar 0,149 dan ini berarti lebih besar dari nilai signifikan $(0,05)$. Berdasarkan hal ini, maka Ho1 diterima sehingga dapat dikatakan bahwa jumlah dewan komisaris tidak berpangaruh terhadap ROE.

b. Data pada Tabel 6.10 dan 6.11 memperlihatkan bahwa nilai dari probabilitas variabel KDK sebesar 0,899 dan 0,146 atau lebih besar dari nilai signifikansi $(0,05)$. Ini berarti Ho2 diterima, sehingga dapat dikatakan komposisi dewan komisaris tidak berpengaruh positif signifikan pada kinerja keuangan perusahaan (ROA dan ROE).

c. Data pada Tabel 6.10 dan 6.11 memperlihatkan bahwa nilai dari probabilitas variabel SIZE sebesar 0,000 dan 0,000 atau lebih kecil dari nilai signifikansi $(0,05)$. Ini berarti Ho3 ditolak, sehingga dapat dikatakan bahwa ukuran perusahaan berpengaruh positif signifikan pada kinerja keuangan perusahaan (ROA dan ROE).

d. Data pada Tabel 6.10 dan 6.11 memperlihatkan bahwa nilai dari probabilitas variabel NPL sebesar 0,000 dan 0,004 atau lebih kecil dari nilai signifikansi $(0,05)$. Ini berarti Ho4 ditolak, sehingga dapat dikatakan bahwa terdapat non-performing loan berpengaruh negatif signifikan terhadap kinerja keuangan perusahaan (ROA dan $\mathrm{ROE})$.

e. Terhadap ROA, data pada Tabel 6.10 memperlihatkan bahwa nilai dari probabilitas variabel LEV sebesar 0,000 atau lebih kecil dari nilai signifikansi $(0,05)$. Ini berarti Ho5 ditolak, sehingga dapat dikatakan bahwa financial leverage berpengaruh negatif signifikan terhadap ROA. Sedangkan terhadap ROE, dari Tabel 6.11 diketahui nilai probabilitas variabel LEV sebesar 0,325 atau lebih besar dari nilai signifikansi $(0,05)$. Ini berarti bahwa Ho5 diterima sehingga dapat dikatakan bahwa financial leverage tidak berpengaruh terhadap ROE. Hasil ini tidak sejalan dengan peneltian Pathan et al., (2007) yang menyatakan bahwa leverage berhubungan negatif dengan kinerja bank.

\section{Uji Signifikansi Simultan (Uji F)}

untuk mengetahui pengaruh Jumlah Dewan Komisaris, Komposisi Dewan Komisaris, Ukuran Perusahaan, Non-performing Loans (NPL), dan Financial Leverage secara bersama-sama (simultan) terhadap ROA dan ROE, dilakukan uji $F$ dengan hasil sebagai berikut: 
Tabel 6.12

ANOVA $^{\mathrm{b}}$

\begin{tabular}{|c|c|c|c|c|c|c|}
\hline \multicolumn{2}{|c|}{ Model } & $\begin{array}{l}\text { Sum of } \\
\text { Squares }\end{array}$ & df & Mean Square & $\mathrm{F}$ & Sig. \\
\hline \multirow[t]{3}{*}{1} & Regression & 114.737 & 5 & 22.947 & 21.067 & $.000^{a}$ \\
\hline & Residual & 110.018 & 101 & 1.089 & & \\
\hline & Total & 224.755 & 106 & & & \\
\hline
\end{tabular}

a. Predictors: (Constant), NPL, LEV, JDK, KDK, SIZE

b. Dependent Variable: ROA

Tabel 6.13

ANOVA $^{\mathrm{b}}$

\begin{tabular}{|ll|r|r|r|r|r|}
\hline \multicolumn{1}{|l|}{} & \multicolumn{1}{|c|}{$\begin{array}{c}\text { Sum of } \\
\text { Model }\end{array}$} & \multicolumn{1}{|c|}{ Squares } & df & Mean Square & F & Sig. \\
\hline 1 & Regression & 5540.812 & 5 & 1108.162 & 8.520 & $.000^{\mathrm{a}}$ \\
& Residual & 13136.975 & 101 & 130.069 & & \\
& Total & 18677.787 & 106 & & & \\
\hline
\end{tabular}

a. Predictors: (Constant), NPL, LEV, JDK, KDK, SIZE

b. Dependent Variable: ROE

Berdasarkan tabel 6.12 dan 6.13 diatas terlihat bahwa nilai signifikansi $(0,000)<$ 0,05. Ini menunjukkan bahwa jumlah dewan komisaris, komposisi dewan komisaris, ukuran perusahaan, non-performing loan, dan financial leverage secara bersama - sama berpengaruh signifikan pada kinerja keuangan perusahaan (ROA dan ROE).

\section{Koefisien Determinasi}

Tabel 6.14

Model Summary

\begin{tabular}{|l|c|r|r|r|}
\hline Model & R & R Square & $\begin{array}{c}\text { Adjusted R } \\
\text { Square }\end{array}$ & $\begin{array}{c}\text { Std. Error of } \\
\text { the Estimate }\end{array}$ \\
\hline 1 & $.714^{\mathrm{a}}$ & .510 & .486 & 1.04369 \\
\hline
\end{tabular}

Tabel 6.15

Model Summary

\begin{tabular}{|l|r|r|r|r|}
\hline Model & $\mathrm{R}$ & $\mathrm{R}$ Square & $\begin{array}{c}\text { Adjusted R } \\
\text { Square }\end{array}$ & $\begin{array}{c}\text { Std. Error of } \\
\text { the Estimate }\end{array}$ \\
\hline 1 & $.545^{\mathrm{a}}$ & .297 & .262 & 11.40478 \\
\hline
\end{tabular}

a. Predictors: (Constant), NPL, LEV, JDK, KDK, SIZE

Nilai koefisien determinasi (Adjusted R Square ) pada Tabel 6.14 menunjukkan bahwa sebesar 0,486 atau sebesar $48,6 \%$ variasi variabel ROA dapat dijelaskan oleh 
variabel JDK, KDK, SIZE, LEV, NPL secara bersama-sama. Sedangkan sisanya, sebesar $52,4 \%$ dipengaruhi oleh faktor lain diluar penelitian ini.

Sedangkan Tabel 6.15 menunjukkan bahwa variasi variabel ROE dapat dijelaskan oleh variabel JDK, KDK, SIZE, LEV, NPL secara bersama-sama adalah sebesar 0,262 atau $26,2 \%$. Sedangkan $73,8 \%$ sisanya dipengaruhi oleh faktor lain diluar penelitian ini.

\section{G. Kesimpulan}

1. Jumlah dewan komisaris (JDK) berpengaruh negatif signifikan terhadap ROA. Jumlah yang kecil ternyata lebih efektif, lebih bernilai tambah, komunikasi dan koordinasi antar anggota dewan menjadi lebih baik, dan menjadi tidak mudah untuk dikendalikan oleh direktur perusahaan.

Tetapi ternyata Jumlah dewan komisaris (JDK) tidak berpengaruh negatif signifikan terhadap ROE.

2. Komposisi dewan komisaris tidak berpengaruh terhadap kinerja keuangan perusahaan (ROA dan ROE).

3. Ukuran perusahaan berpengaruh signifikan positif terhadap kinerja keuangan perusahaan (ROA dan ROE). Semakin besar ukuran perusahaan dan dengan pengelolaan yang baik akan membuat perusahaan mampu menambah keuntungannya sehingga kinerja akan meningkat.

4. Non-performing loan berpengaruh negatif signifikan terhadap ROA dan ROE. Hasil ini sesuai pendapat penelitian yang dilakukannya, Pathan et al., (2007) yang juga menemukan hubungan yang negatif antara besarnya NPL dengan ROA dan ROE. Dengan tingginya NPL maka akan semakin besar pula pencadangan yang harus dibuat. karena pencadangan ini diambilkan dari beban / biaya perusahaan maka hal ini akan secara langsung mempengaruhi kinerja keuangan perusahaan.

5. Financial leverage berpengaruh negatif signifikan terhadap ROA tetapi tidak berpengaruh terhadap ROE. Berpengaruh negatif signifikan terhadap ROA berarti semakin besar penggunaan hutang oleh perusahaan maka ROA akan menurun.

6. Berdasarkan hasil uji $F$ dapat disimpulkan bahwa keempat variabel secara serempak berpengaruh terhadap kinerja keuangan perusahaan (ROA dan ROE) pada tingkat signifikansi $5 \%$.

\section{H. Daftar Pustaka}

Abdullah, Shamsul Nahar. (2004), Board composition, CEO duality and performance among Malaysian listed companies, Corporate Governance, Vol. 4 No. 4.

Alijoyo, Antonius dan Zaini, S. (2004), Komisaris Independen: Penggerak Praktek GCG di Perusahaan, Indeks, Jakarta.

Bhagat, Sanjai and Black, Bernard S. (2002), The Non-Correlation Between Board Independence and Long-Term Firm Performance, Journal of Corporation Law, Winter, Vol. 27 No. 2.

Bauer, Rob, Guenster, Nadja and Otten, Roger. (2004), Empirical evidence on corporate governance in Europe: The effect on stock returns, firm value and performance, Journal of Asset Management, Vol. 5 No. 2, 91-104.

Carter, David A., Simkins, Betty J., and Simpson, W. Garry. (2003), Corporate Governance, Board Diversity, and Firm Value, The Financial Review 38, 33-53. 
Choi, Sungho., and Hasan, Iftekhar. (2005), Ownership, Governance, and Bank Performance: Korean Experience, Financial Market, Institutions \& Instruments, November, Vol. 14 No.4.

Chiang, Hsiang-tsai.(2005), An Empirical Study of Corporate Governance and Corporate Performance, Journal of American Academy of Business, Cambridge, March, Vol. 6 No. 1.

Daniri, Mas Achmad. (2005), Good Corporate Governance: Konsep dan Penerapannya dalam konteks Indonesia, Ray Indonesia, Jakarta.

Dwivedi, Neeraj., and Jain, Arun Kumar. (2005), Corporate Governance and Performance of Indian Firms: The Effect of Board Size and Ownership, Employee Responsibilities and Rights Journal, September, Vol. 17 No. 3.

Kiel, G. C., and Nicholson, G. J. (2003), Board composition and corporate performance: How the Australian experience informs contrasting theories of corporate governance. Corporate Governance: An Internasional Review, Vol. 11 (3).

Kyereboah - Coleman, A, and Biekpe, N. (2006), The link between corporate governance and performance of the non-traditional export sector: evidence from Ghana, Corporate Governance, Vol.6 No.5.

Kyereboah - Coleman, A, and Biekpe, N. (2006), The relationship between board size, board composition, CEO duality and firm performance: Experience from Ghana. Corporate Ownership \& Control 2006, Vol.4 (2), 114-122.

Lam, Tin Yan, and Lee, Shu Kam. (2008), CEO duality and firm performance: evidence from Hong Kong, Corporate Governance, Vol.8 No.3

Macey, Jonathan R., and O'Hara Maureen. (2003), The Corporate Governance of Banks, FRBNY Economic Policy Review, April.

Miyajima, H., Omi, Y., Saito, N. (2003), Corporate Governance and Performance in Twentieth Century Japan, Business and Economic History, Vol. 1, 1-36

Nachrowi, Nachrowi D., dan Usman, Hardius. (2006), Pendekatan Populer dan Praktis Ekonometrika Untuk Analisis Ekonomi dan Keuangan, LP FE UI, Jakarta.

Pathan, S., Skully, M., \& Wickramanayake, J. (2007), Board Size, Independence and Performance : An analysis of Thai Banks, Asia-Pasifik Finan Market, 14:211-227.

Peraturan Bank Indonesia nomor 8/4/PBI/2006 tentang Pelaksanaan Good Corporate Governance Bagi Bank Umum

Peraturan Bank Indonesia nomor 8/14/PBI/2006 tentang Perubahan Atas Peraturan Bank Indonesia nomor 8/4/PBI/2006

Rose, Peter S, and Hudgins, Sylvia C. (2005), Bank Management \& Financial Services, McGraw-Hill, Singapore.

Sanda, A., Mikailu, Aminu S., and Garba, Tukur. (2005), Corporate Governance mechanisms and firm financial performance in Nigeria, AERC Research Paper 149, African Economic Research Consortium.

Surat Edaran Bank Indonesia No. 9/12/DPNP tanggal 30 Mei 2007 perihal Pelaksanaan Good Corporate Governance bagi Bank Umum

Truong, Thanh. (2006), Corporate Boards, Ownership and Agency Cost: Evidence from Australia, The Business Review, Cambridge, Summer, Vol. 5 No. 2.

Undang-undang Republik Indonesia nomor 40 tahun 2007 mengenai Perseroan Terbatas

Utomo, Yuni Prihadi. (2007), Eksplorasi Data dan Analisis Regresi dengan SPSS, Muhammadiyah Univeersity Press, Universitas Muhammadiyah Surakarta, Surakarta. 